\title{
Stearoyl-CoA Desaturase Activity and Gene Expression in the Adipose Tissue of Buffalo Bulls Was Unaffected by Diets with Different Fat Content and Fatty Acid Profile
}

\author{
Piera Iommelli ${ }^{1}$, Federico Infascelli ${ }^{1}$, Nadia Musco ${ }^{1, *} \mathbb{1}$, Micaela Grossi ${ }^{1}$, Maria Ferrara ${ }^{1}$, Fiorella Sarubbi ${ }^{2}$, \\ Biagio D'Aniello ${ }^{3}{ }^{(0)}$, Pietro Lombardi ${ }^{1,+}$ and Raffaella Tudisco ${ }^{1,+}+(\mathbb{C}$ \\ 1 Department of Veterinary Medicine and Animal Production, University of Napoli Federico II, \\ 80100 Napoli, Italy; pieraiommelli@gmail.com (P.I.); federico.infascelli@unina.it (F.I.); \\ micaelagrossi@tiscali.it (M.G.); maria.ferrara@unina.it (M.F.); pietro.lombardi@unina.it (P.L.); \\ tudisco@unina.it (R.T.) \\ 2 Institute for the Animal Production System in the Mediterranean Environment, National Research Council, \\ 80055 Portici, Italy; fiorella.sarubbi@cnr.it \\ 3 Department of Biology, University of Napoli Federico II, 80100 Napoli, Italy; biagio.daniello@unina.it \\ * Correspondence: nadia.musco@unina.it \\ + These authors contributed equally to this work.
}

check for updates

Citation: Iommelli, P.; Infascelli, F.; Musco, N.; Grossi, M.; Ferrara, M.; Sarubbi, F.; D’Aniello, B.; Lombardi, P.; Tudisco, R. Stearoyl-CoA Desaturase Activity and Gene Expression in the Adipose Tissue of Buffalo Bulls Was Unaffected by Diets with Different Fat Content and Fatty Acid Profile. Agriculture 2021, 11, 1209. https://doi.org/10.3390/ agriculture11121209

Academic Editors: Vito Laudadio and Vincenzo Tufarelli

Received: 8 November 2021

Accepted: 28 November 2021

Published: 1 December 2021

Publisher's Note: MDPI stays neutral with regard to jurisdictional claims in published maps and institutional affiliations.

Copyright: () 2021 by the authors. Licensee MDPI, Basel, Switzerland. This article is an open access article distributed under the terms and conditions of the Creative Commons Attribution (CC BY) license (https:// creativecommons.org/licenses/by/ $4.0 /)$.
Abstract: Research on diet effects on buffalo meat quality may be critical to assess its possible consumption benefits in human nutrition. This study investigated, in growing buffalo bulls, the effects of two diets differing in total fat content and fatty acid profile on the activity and gene expression of Stearoyl-CoA Desaturase (SCD) in the adipose tissue and on meat quality. Twenty buffalo bulls, 6 months old, were randomly assigned to the two dietary treatments until slaughtering (about $400 \mathrm{~kg}$ body weight). No significant difference between the groups was observed for chemical composition, fatty acid profile and CLAs content of Longissimus thoracis as well as for the SCD gene expression. Such results seem to be in contrast with similar studies performed on other ruminant species, but confirm that important differences occur between buffalo and bovine species, such as the lower content in fat of buffalo meat. Our results also confirm that specific studies should be performed on buffalo, also in terms of the metabolic pathways activated by different diets.

Keywords: Stearoyl-CoA desaturase; diet fatty acids; buffalo

\section{Introduction}

Compared to the other domesticated ruminants, the water buffalo (Bubalus bubalis) shows specific traits for digestive physiology [1-3] and milk quality [4-6]. In recent years, interest in buffalo meat has progressively increased due to its nutritional characteristics, mainly regarding the fatty acids profile, which appeared able to play a positive role in human health [7]. Particular attention has been focused on conjugated linoleic acids (CLAs) due to their anti-carcinogenic activity, their positive effects on diabetic patients and on the proper function of the immune and cardiovascular systems [8,9]. CLAs have two origins [10]: (1) through the bio-hydrogenation of some unsaturated fatty acids in the rumen, and (2) through the endogenous synthesis starting from trans-vaccenic acid (trans11 C18:1, TVA-intermediate product of linoleic and $\alpha$-linolenic bio-hydrogenation) by a $\triangle 9$-desaturase, the Stearoyl CoA Desaturase (SCD). According to Griinari et al. [11], the contribution of endogenous synthesis to the total content of CLAs in milk (through TVA desaturation by $\Delta 9$-desaturase in the mammary gland) should be almost $64 \%$, while Lock and Garnsworthy [12] and Piperova et al. [13] estimated an incidence higher than $80 \%$ and $90 \%$, respectively. According to Kay et al. [14], endogenous synthesis should be up to $100 \%$, and such a hypothesis was supported by the observation that the concentration of CLAs in the blood was very low [15]. Gillis et al. [16] reported that around $86 \%$ of the cis-9, trans-11 
CLA in the bovine intramuscular fat comes from the TVA desaturation. Concerning other ruminants, little is known on the proportion of rumen and endogenous origin of CLAs. High CLAs levels in lamb meat were associated with high TVA levels [17], suggesting the endogenous synthesis plays a fundamental role also in small ruminants. The $\Delta 9$-desaturase, in addition to producing cis-9, trans-11 CLA, also plays a part in producing trans-7, cis-9 and cis-9, trans-13 CLA, as identified by Yurawecz et al. [18]. The Stearoyl-CoA desaturase (SCD) is a multi-enzymes complex including NADH-cytochrome-b5 reductase, cytochrome b5, acil-CoA synthase and $\Delta 9$-desaturase. The SCD gene encodes a protein of 359 amino acid residues, located in the endoplasmic reticulum, that catalyzes the $\Delta-9$ desaturation, introducing a cis double bound, of a spectrum of fatty acyl-CoA substrates, mainly from myristic (C14) to nonadecylic (C19) acid between carbon 9 and 10. The products of this reaction are important components of phospholipids and triglycerides mainly involved in cell membrane fluidity. In ruminants' mammary glands and adipose tissue, SCD acts on the rumen biohydrogenation of trans-11 C18:1 (TVA, transvaccenic acid), an intermediate product of polyunsaturated fatty acids (PUFA) [11], to synthesize the CLAs. Up to $80 \%$ of CLAs in the food is represented by the cis-9, trans-11 CLA (rumenic acid), which derives from linoleic acid [19]. In ruminants, the SCD gene generates a 5-kilobyte (KB) transcript that was characterized in sheep [20], cows [21], and goats [22]. It is organized in 6 exons and 5 introns. The water buffalo SCD gene spans approximately 15.5 KB (EMBL Acc. No. AM600640) and its polymorphism seems to affect its expression in the mammary gland [23] and muscles [24]. These last authors characterized the water buffalo SCD gene, showing 15 polymorphic sites, one of which, realized at the 231st nucleotide of exon 5, is responsible for an amino acid change (GCGAlaGTGVal). As observed in the cow [25], such a transition could be associated with a different content of monounsaturated fatty acids (MUFA) in buffalo milk and meat. SCD gene expression is known to be affected by several factors: animal species, tissue, diet, age [26], CLAs [27] and cholesterol content [28]. In rodents, regulation of SCD gene expression by dietary factors has been mainly investigated in liver and adipose tissue [29] and in the mammary gland [30]. In these species, SCD relies on different genes whose expression is tissue-specific as well as their down-regulation by PUFA [29]. In contrast, in sheep [20] and goats [22], there is only one SCD gene, and, according to Bernard et al. [31], in the ruminants' mammary gland and adipose tissue, it is less sensitive to dietary PUFA intake. Indeed, Daniel et al. [32] reported a SCD gene downregulation in the adipose tissue of lambs fed forage compared with those fed a concentrate-based diet due to the higher content of linolenic acid (C18:3n-3) in the forage. Similar results were reported in our previous studies on SCD gene expression in the mammary gland of goats fed on pasture [33-35] or with a diet rich in linolenic acid [36,37].

Concerning the effect of a high fat diet (HFD) on SCD gene expression, conflicting results were reported in studies on rats: increase [38,39], decrease [40] or no alteration $[41,42]$. In buffalo species, SCD gene expression or activity were studied by several authors $[5,23,24,43-47]$ in the mammary gland, while, to the best of our knowledge, no research was performed in the adipose tissue. Therefore, the aim of present trial was to study the effect of different total fat and PUFA content in the diet on the activity and expression of the SCD gene in the adipose tissue of buffalo bulls.

\section{Materials and Methods}

The trial, performed according to the Animal Welfare and Good Clinical Practice (Directive 2010/63/EU) and approved by the local Bioethics Committee (protocol number: PG/2021/0044033), was carried out at a buffalo farm located on an irrigated area $\left(41^{\circ} 26^{\prime} 27^{\prime \prime}\right.$ $\mathrm{N}, 13^{\circ} 50^{\prime} 00^{\prime \prime} \mathrm{E}, 40 \mathrm{~m}$ a.s.l.) of Cassino, province of Frosinone (South-Italy), with $961 \mathrm{~mm}$ and $14.9^{\circ} \mathrm{C}$ average annual rainfall and temperature, respectively. Twenty 6-month-old male buffalo calves, placed in individual pens with free access to clean water, were divided into two homogeneous groups (low fat, LF and high fat, HF) and fed diets (100 g DM $/ \mathrm{kg}$ of metabolic weight) constituted by corn silage ( $32 \% \mathrm{DM})$, oat hay $(18 \% \mathrm{DM})$ and two different concentrates (50\% DM): LF (corn $10 \%$, barley $14 \%$, wheat bran $28 \%$, fava bean $31 \% \mathrm{CP}$ 
tannin-free variety $48 \%$ ) and $\mathrm{HF}$ (corn $18 \%$, barley $16 \%$, wheat bran $18 \%$, soybean $33 \% \mathrm{CP}$ $48 \%$ ). Refusals weremeasured daily. Monthly, feeds and diets' chemical compositions were analyzed according to AOAC methods [48] for dry matter (DM, ID 934.01), crude protein (CP, ID 984.13), and ether extract (EE, ID 920.29) while the structural carbohydrates were determined as suggested by Van Soest et al. [49] and nutritive values were calculated [50]. The diets were also analyzed for their fatty acid profile through the total fat extraction according to Folch et al. [51] and fatty acid methylation as suggested by Christie [52]. Fatty acid methyl esters were analyzed by a gas-chromatograph Focus (Thermo Scientific Co. Waltham, MA, USA, 02451) equipped with a $S P^{\circledR}-2380$ fused silica capillary column $(100 \mathrm{~mL} \times 0.25 \mathrm{~mm}$ internal diameter with $0.2 \mu \mathrm{m}$ film thickness (Uspelco, Inc, Bellefonte, PA, USA)) using the AS 3000 II autosampler. The gas-chromatograph conditions were: oven temperature at $160^{\circ} \mathrm{C}$ and held for $1 \mathrm{~min}$, successively increased up to $230^{\circ} \mathrm{C}$ at a rate of $1{ }^{\circ} \mathrm{C} / \mathrm{min}$ and held for $3 \mathrm{~min}$; the temperature of injector and detector set at $220{ }^{\circ} \mathrm{C}$ and $250{ }^{\circ} \mathrm{C}$, respectively; helium as the carrier gas with a flow of $1.5 \mathrm{~mL} / \mathrm{min}$. Fatty acids were identified by comparing retention times of peaks with those of the fatty acids standard mixture (Larodan Fine Chemical AB, Malmo, Sweden). The animals were slaughtered when they reached $400 \mathrm{~kg}$ live weight $(480.4 \pm 35.4$ days of age) in an authorized slaughterhouse according to EU legislation (EU Regulation 882/2004). After 14 days of ageing at $4 \pm 1{ }^{\circ} \mathrm{C}$, a sample cut corresponding to the Longissimus thoracis (LT) was collected for moisture, crude fat, ash and protein analysis by a food analyzer (FoodScan Lab, FOSS Electric, Denmark) and to study the intra-muscular fatty acid profile. To this purpose, total lipids were extracted in duplicate, from $5 \mathrm{~g}$ ground meat sample, according to Folch [51]. Fatty acids were methylated as described by Christies [52] with $\mathrm{NAOH} / \mathrm{MeOH}$ followed by $\mathrm{HCl} / \mathrm{MeOH}$ and analyzed with gas chromatography apparatus (Thermoquest 8000 tops series, with a system of computerized integration "Millennium 32"), equipped with a CP-SIL 88 fused silica capillary column $100 \mathrm{~m} \times 0.25 \mathrm{~mm}$ (internal diameter) with 0.2-mL film thickness (Varian, Walnut Creek, CA, USA). Gas chromatograph conditions were set as follows: initial oven temperature maintained at $70{ }^{\circ} \mathrm{C}$ for $4 \mathrm{~min}$, then ramped up by $13^{\circ} \mathrm{C} / \mathrm{min}$ to $175^{\circ} \mathrm{C}$ and maintained for $27 \mathrm{~min}$, then ramped to $215^{\circ} \mathrm{C}$ by $3^{\circ} \mathrm{C} / \mathrm{min}$ and maintained for $38 \mathrm{~min}$, before reverting to $70{ }^{\circ} \mathrm{C}$ at a rate of $10{ }^{\circ} \mathrm{C} / \mathrm{min}$. Inlet and detector temperatures were 250 and $260{ }^{\circ} \mathrm{C}$, respectively. The split ratio was 100:1. The helium carrier gas flow rate was $1 \mathrm{~mL} / \mathrm{min}$, hydrogen flow to the detector was $30 \mathrm{~mL} / \mathrm{min}$, airflow was $350 \mathrm{~mL} / \mathrm{min}$ and the flow of helium carrier gas was $45 \mathrm{~mL} / \mathrm{min}$. Fatty acid peaks were identified using pure methyl ester external standards (Larodan Fine Chemicals, AB, Malmo, Sweden). Additional standards for CLA isomers were obtained from Larodan.

\subsection{Sampling and Extraction of Total RNA from Subcutaneous Adipose Tissue}

Immediately after slaughtering, samples of subcutaneous adipose tissue were taken from the right side of each carcass (between the 12th and 13th ribs) under RNase-free conditions, snap-frozen in liquid nitrogen and stored at $-80{ }^{\circ} \mathrm{C}$ until further analysis.

The total RNA in the adipose tissue was used for SCD gene expression analysis. Two hundred $\mathrm{mg}$ of tissue were placed into $2 \mathrm{~mL}$ microcentrifuge tubes on ice containing one stainless steel bead (5 mm mean diameter) and $600 \mu \mathrm{L}$ Buffer RLT (lysis buffer, Qiagen). Each tube was placed in the TissueLyser Adapter Set $2 \times 24$ and the tissues were homogenized two times with the TissueLyser instrument (Qiagen, Hilden, Germany) for 2 min at $20 \mathrm{~Hz}$ and centrifuged for $3 \mathrm{~min}$ at 10,000 rpm. The expression levels of SCD gene were studied by extraction of total RNA from subcutaneous adipose tissue using the RNeasy Mini Kit (Qiagen, Hilden, Germany) following the manufacturer's instructions. RNA was dissolved in $50 \mu \mathrm{L}$ of RNase-free water and stored at $-80{ }^{\circ} \mathrm{C}$.

\subsection{Single-Strand cDNA Synthesis}

Total RNA concentration and purity were evaluated through absorbance readings (ratio of A260/A230 and A260/A280) by using a bio-photometer (Eppendorf, Hamburg, Germany). RNA quality was determined using an Agilent 2100 Bioanalyzer instrument 
(Agilent Technologies, Santa Clara, CA, USA), based on microcapillary electrophoresis. With this technology, electropherograms and gel-like images can be visually evaluated, and expert software can generate an RNA Integrity Number (RIN), a user-independent assessment of RNA integrity.

Total RNA $(1 \mu \mathrm{g})$ was incubated in gDNA Wipeout buffer (Qiagen) at $42{ }^{\circ} \mathrm{C}$ for $2 \mathrm{~min}$ to effectively remove contaminating genomic DNA. Then, first-strand cDNA was reverse transcribed using a Quantiscript Reverse transcriptase (Qiagen) according to the manufacturer's instructions. The obtained single strand cDNA was diluted in diethylpyrocarbonatetreated water (1:50) and stored at $-20^{\circ} \mathrm{C}$.

\subsection{Quantitative Real-Time PCR Analysis}

Quantitative real-time PCR was performed using five-fold diluted cDNA products with SYBR ${ }^{\circledR}$ Green PCR Master Mix (Applied Biosystem). Analysis was carried out with an ABI Prism 7300 System (Applied Biosystem, Foster City, CA, USA), with software for data management (PE Biosystems 7300 software) for 40 cycles at $95{ }^{\circ} \mathrm{C}$ for $20 \mathrm{~s}$ and amplification at $60^{\circ} \mathrm{C}$ for $1 \mathrm{~min}$. Each sample was run in triplicate with a non-template control included. A melting curve was produced after completion of the thermal PCR program to check for the presence of one gene-specific peak and the absence of primer-dimers. Specific gene primers were: SCD as described by Gu et al. (2019), or $\beta$-actin, 18 rRNA [24] and glyceraldehyde-3-phosphate-dehydrogenase (GAPDH) [47], as housekeeping genes. Primer pairs were verified by determining the amplification efficiency with five serial dilutions (1:4) of the cDNA template. All threshold cycle (Ct) values of the samples fell on the linear range of the curves. The amplification efficiency of housekeeping genes was $100 \%$ and $95.8 \%$ for SCD gene. The relative gene expression levels were calculated by normalizing the threshold cycle numbers $(\mathrm{Ct})$ of the SCD mRNA using the mean $\mathrm{Ct}$ of housekeeping genes. Results were expressed as arbitrary units (AU) (Table 1).

Table 1. Pairs of primers used for Real Time PCR.

\begin{tabular}{|c|c|c|c|c|}
\hline & Sequence $\left(5^{\prime}->3^{\prime}\right)$ & $\operatorname{Tm}\left({ }^{\circ} \mathrm{C}\right)$ & Product Length (bp) & References \\
\hline GAPDH-F & TGGAAAGGCCATCACCATCT & 60 & 119 & Li et al. 2020 \\
\hline GAPDH-R & CCCACTTGATGTTGGCAG & & & \\
\hline Actin-F & ТССТСССТGGAGAAGAGCTA & & & \\
\hline Actin-R & AGGAAGGAAGGCTGGAAGAG & 60 & 101 & Gu et al. 2019 \\
\hline 18S rRNA-F & CGTTCTTAGTTGGTGG & & & \\
\hline 18S rRNA-F & GTAACTAGTTAGCATGC & 60 & 76 & Gu et al. 2019 \\
\hline SCD F & CAGCGGAAGGTCCCGA & & & \\
\hline SCD R & CAAGTGGGCCGGCATC & 60 & 157 & Gu et al. 2019 \\
\hline
\end{tabular}

\subsection{Statistical Analysis}

Data were processed by one-way ANOVA according to this model:

$$
Y i j=\mu+D i+\varepsilon i j
$$

where Yij $=$ mean of response variable, $\mu=$ population mean, $\mathrm{Di}=$ effect of $\operatorname{diet}(\mathrm{i}=1,2)$ and $\varepsilon=$ experimental error.

The differences between the mean values were analyzed by using Tukey's test. Differences were considered statistically significant at $p<0.05$ and $p<0.01$. All the analyses were performed by JMP software v.11 [53].

\section{Results and Discussion}

In Table 2, the chemical composition and the nutritive value of feeds and diets are reported. The diets were isoproteic, while the fat content was significantly higher $(p<0.01)$ in the HF diet than in the LF one (g/kg DM 71.1 vs. 23.1), due to the higher level of lipids 
in HF concentrate (g/kg DM 120.7) compared to LF concentrate (g/kg DM 23.1). The structural carbohydrates and the lignin were also significantly higher in $\mathrm{HF}$ diet $(\mathrm{g} / \mathrm{kg} \mathrm{DM}$ 275.4 vs. $197.5 ; p<0.01)$; thus, the diets' nutritive value was similar $(0.90$ vs. $0.91 \mathrm{VFU} / \mathrm{kg}$ $\mathrm{DM}$, for LF and HF, respectively).

Table 2. Feeds and diets chemical composition (g/kg DM) and nutritive value (VFU/kg DM).

\begin{tabular}{|c|c|c|c|c|c|c|c|}
\hline & CS & $\mathrm{OH}$ & LFC & HFC & LF Diet & HF Diet & SEM \\
\hline $\mathrm{CP}$ & 77.2 & 90.1 & 220.0 & 220.0 & 140.6 & 140.9 & 4.34 \\
\hline EE & 21.0 & 22.2 & 24.7 & 120.7 & $23.1 \mathrm{~B}$ & $71.1 \mathrm{~A}$ & 1.92 \\
\hline NDF & 482.2 & 560.0 & 216.1 & 233.2 & 363.0 & 381.6 & 8.46 \\
\hline $\mathrm{ADF}$ & 272.1 & 370.0 & 87.6 & 103.4 & 197.5 B & $275.4 \mathrm{~A}$ & 12.67 \\
\hline ADL & 31.3 & 38.1 & 12.2 & 21.4 & 24.2 & 27.3 & 1.03 \\
\hline VFU/kg DM & 0.77 & 0.63 & 1.08 & 1.10 & 0.90 & 0.91 & 0.01 \\
\hline
\end{tabular}

CS: corn silage; OH: oat hay; VFU: veal forage unit. LFC (low fat concentrate; $\%$ DM): corn 10, barley 14, wheat bran 28 , faba bean ( $31 \%$ CP tannin-free variety) 48 . HFC (high fat concentrate; $\%$ DM): corn 18, barley 16, wheat bran 18, soybean (33\% CP) 48. A-B: $p<0.01$.

No dietary refusals were detected. Dietary PUFA (C18:2 cis 9 cis $12+\mathrm{C} 18: 3$ cis 9 cis 12 cis15) intake was 3.35 time higher with HF than LF diet (Table 3), even if the intake of linolenic acid (C18:2 cis 9 cis 12) was the main contributor to this result; according to Calabrò et al. [54], these results are due to the different fatty acids profile of the main ingredient of concentrate of the two diets, fava bean in LF vs. soybean in HF. Indeed, fava has been shown to have a higher $\mathrm{C} 18: 3$ and lower $\mathrm{C} 18: 2$ content than soybean.

Table 3. Dietary main fatty acid intake (g/kg DM).

\begin{tabular}{ccc}
\hline & LF Diet & HF Diet \\
\hline C14:0 & 0.02 & 0.14 \\
C16:0 $16: 1$ & 2.29 & 7.54 \\
C18:0 & 0.02 & 0.06 \\
C18:1 cis 9 & 0.62 & 1.49 \\
C18:1 cis 11 & 2.84 & 11.6 \\
C18:2 cis 9 cis 12 & 0.18 & 1.07 \\
C18:3 cis 9 cis12 cis15 & 7.97 & 28.40 \\
C20:0 & 1.59 & 3.70 \\
C22:0 & 0.09 & 0.14 \\
\end{tabular}

The dietary treatment did not affect the chemical composition of Longissimus thoracis (Table 4) or its fatty acid profile (Table 5).

Table 4. Longissimus thoracis chemical composition.

\begin{tabular}{ccc}
\hline & LF & HF \\
\hline Moisture \% & 75.3 & 75.4 \\
Fat \% & 1.8 & 1.9 \\
Protein \% & 21.4 & 21.2 \\
Ash \% & 0.71 & 0.70 \\
\hline
\end{tabular}

In particular, myristic and palmitic acid, known to be significantly associated with the risk of cardiovascular disease [55], showed similar levels in the Longissimus thoracis of the two buffalo groups. In contrast, Scerra et al. [56] found higher levels of palmitic acid in meat from lambs fed concentrate containing soybean vs. fava bean. In the present study, the content of stearic acid in LT did not differ between the two buffalo groups, while Cutrignelli et al. [57], comparing the fatty acid profile of meat from bulls of Marchigiana breed fed concentrate with fava bean vs. soybean, found a significantly $(p<0.01)$ higher concentration of stearic acid in the first group. Oleic acid was the most represented fatty 
acid in the LT from both groups. It is well known that this fatty acid originates from the desaturation, through SCD activity, of the stearic acid coming from the biohydrogenation of linoleic and linolenic acids in the rumen [58]. A strong effect of ruminant dietary regimen on oleic acid levels in meat was reported, both in beef [59,60] and in sheep tissues [61], as partially depending on an increased activity of SCD. In the present trial, even if the intake of linoleic acid was higher in the HF diet, the levels of oleic acid in LT were similar between the two groups. Likewise, LT linoleic, linolenic and CLAs content were not different between groups.

Table 5. Fatty acids composition of Longissimus thoracis muscle (g/100 g FA).

\begin{tabular}{|c|c|c|c|c|}
\hline Acids & & LF & HF & SEM \\
\hline Myristic & C14:0 & $1.25 \pm 0.2$ & $1.18 \pm 0.1$ & 0.336 \\
\hline Myristoleic & C14:1 cis-9 & $0.47 \pm 0.07$ & $0.47 \pm 0.02$ & 0.039 \\
\hline Pentadecylic & $\mathrm{C} 15: 0$ iso & $0.17 \pm 0.02$ & $0.16 \pm 0.02$ & 0.010 \\
\hline Methyltetradecanoic & $\mathrm{C} 15: 0$ ante iso & $0.21 \pm 0.1$ & $0.24 \pm 0.09$ & 0.009 \\
\hline Palmitic & C16:0 & $20.9 \pm 0.7$ & $21.0 \pm 0.9$ & 0.478 \\
\hline Palmitoleic & C16:1 & $1.13 \pm 0.17$ & $1.17 \pm 0.04$ & 0.162 \\
\hline Margaric & C17:0 & $1.20 \pm 0.3$ & $1.24 \pm 0.3$ & 0.089 \\
\hline Eptadecenoic & C17:1 cis-10 & $0.39 \pm 0.07$ & $0.41 \pm 0.08$ & 0.220 \\
\hline Stearic & C18:0 & $25.1 \pm 2.1$ & $24.6 \pm 1.9$ & 0.370 \\
\hline Octadecenoic & C18:1 trans- 10 & $0.58 \pm 0.05$ & $0.62 \pm 0.07$ & 0.067 \\
\hline trans-Vaccenic & C18:1 trans-11 & $1.32 \pm 0.35$ & $1.30 \pm 0.05$ & 0.067 \\
\hline \multirow[t]{2}{*}{ Oleic } & C18:1 cis-9 & $30.55 \pm 1.5$ & $30.86 \pm 0.6$ & 0.643 \\
\hline & C18:1 cis-11 & $1.20 \pm 0.09$ & $1.20 \pm 0.06$ & 0.660 \\
\hline Linoleic & C18:2 ๑-6 & $7.89 \pm 0.9$ & $7.92 \pm 0.4$ & 0.182 \\
\hline alpha-Linolenic & C18:3 ळ-3 & $0.59 \pm 0.02$ & $0.56 \pm 0.02$ & 0.093 \\
\hline gamma-Linolenic & $\mathrm{C} 18: 3$ ๑-6 & $0.09 \pm 0.01$ & $0.09 \pm 0.01$ & 0.002 \\
\hline Rumenic & cis 9-trans 11 CLA & $0.04 \pm 0.003$ & $0.05 \pm 0.004$ & 0.005 \\
\hline Octa-deca Dienoic & trans10-trans12 CLA & $0.16 \pm 0.01$ & $0.17 \pm 0.03$ & 0.060 \\
\hline Arachidic & C20:0 & $0.21 \pm 0.05$ & $0.24 \pm 0.06$ & 0.093 \\
\hline Gondoic & C20:1 cis-11 & $0.90 \pm 0.09$ & $0.98 \pm 0.05$ & 0.025 \\
\hline Eicosadienoic & C20:2 cis 11,14 & $0.16 \pm 0.06$ & $0.20 \pm 0.06$ & 0.056 \\
\hline Dihomo-gamma-linolenic & C20:3 ळ-6 & $0.52 \pm 0.08$ & $0.40 \pm 0.05$ & 0.096 \\
\hline Eicosapentaenoic & $\mathrm{C} 20: 3$ Ф-3 & $0.28 \pm 0.05$ & $0.21 \pm 0.06$ & 0.023 \\
\hline Arachidonic & $\mathrm{C} 20: 4 \omega-3$ & $1.78 \pm 0.1$ & $1.62 \pm 0.1$ & 0.018 \\
\hline Eicosapentanoic & $C 20: 5 \omega-3$ & $0.21 \pm 0.01$ & $0.22 \pm 0.03$ & 0.067 \\
\hline Behenic & C22:0 & $0.18 \pm 0.01$ & $0.18 \pm 0.02$ & 0.051 \\
\hline Adrenic & $\mathrm{C} 22: 4$ ๑-6 & $0.28 \pm 0.03$ & $0.29 \pm 0.02$ & 0.078 \\
\hline Docosapentanoic & $\mathrm{C} 22: 5 \omega-3$ & $0.41 \pm 0.02$ & $0.40 \pm 0.03$ & 0.049 \\
\hline Docosahexaenoic & $\mathrm{C} 22: 6 \omega-3$ & $0.20 \pm 0.03$ & $0.20 \pm 0.03$ & 0.034 \\
\hline Tricosylic & C23:0 & $0.15 \pm 0.01$ & $0.22 \pm 0.02$ & 0.012 \\
\hline Lignoceric & C24:0 & $0.18 \pm 0.02$ & $0.18 \pm 0.03$ & 0.027 \\
\hline \multirow[t]{2}{*}{ Nervonic } & $\mathrm{C} 24: 1$ cis15 & $0.40 \pm 0.02$ & $0.40 \pm 0.03$ & 0.080 \\
\hline & SFA & $50.6 \pm 0.47$ & $49.9 \pm 0.57$ & 6.231 \\
\hline
\end{tabular}


Table 5. Cont

\begin{tabular}{|c|c|c|c|c|}
\hline Acids & & LF & HF & SEM \\
\hline & MUFA & $36.3 \pm 1.3$ & $36.5 \pm 0.67$ & 3.902 \\
\hline & PUFA & $12.8 \pm 1.2$ & $13.4 \pm 0.48$ & 1.924 \\
\hline & PUFA $₫ 6$ & $8.78 \pm 0.8$ & $8.07 \pm 0.4$ & 1.401 \\
\hline & PUFA ๑3 & $3.47 \pm 0.2$ & $3.21 \pm 0.3$ & 0.530 \\
\hline & ๑6/๑3 & $2.53 \pm 0.3$ & $2.51 \pm 0.3$ & 0.630 \\
\hline & CLA & $0.231 \pm 0.01$ & $0.212 \pm 0.01$ & 0.072 \\
\hline & C14:1 cis-9/C14:0 & $0.376 \pm 0.1$ & $0.398 \pm 0.09$ & 0.106 \\
\hline & C16:1/C16:0 & $0.054 \pm 0.02$ & $0.055 \pm 0.01$ & 0.0042 \\
\hline & C18:1 cis-9/C18:0 & $1.22 \pm 0.3$ & $1.25 \pm 0.2$ & 0.652 \\
\hline
\end{tabular}

SEM: standard error of the mean

SCD activity could be measured by the ratio of product/substrate of some fatty acids. In milk, Lock and Garnsworthy [62] stated that the C14:1 cis 9/C14:0 ratio is the best marker of SCD activity; in fact, C14:0 is entirely de novo synthesized in the mammary gland; thus, C14:1 completely comes from C14:0 desaturation. Consequently, higher values of C14:1 cis 9/C14:0 ratio would indicate an increase of SCD activity. In our trial, this index was unaffected by the treatment: its value was only slightly higher in the LT of group HF (Table 4) without significant differences. In addition, the C16:1/C16:0 and C18:1 cis 9/C18:0 ratios were calculated [63] and for both no difference was detected between groups.

Overall, both chemical and fatty acid composition of the Longissimus thoracis muscle were unaffected by the two diets, and such results seem to be in contrast with similar studies performed on other ruminant species. On the other hand, several authors reported important differences between buffalo and bovine species, one of them being the different fat content of buffalo meat. Our results confirm and underline that specific studies should be performed on buffalo, also in terms of the metabolic pathways activated by diet differences. Importantly, the very low fat percentage represents one of the reasons that justifies the growing interest in buffalo meat, mainly for consumers who need dietetical foods [7]; thus, research on this topic is critical to assess the possible benefits of buffalo meat consumption in human nutrition.

RNA quality and yield extracted from $200 \mathrm{mg}$ of subcutaneous adipose tissue with the modified RNeasy Mini Kit (QIAGEN) were acceptable for the Real Time PCR. All total RNA samples exhibited 260/280 ratios of $>1.8$ and RNA yield averaged $30.5 \mu \mathrm{g} / \mathrm{g}$ in adipose tissue (varied from 18.5-40.7 $\mu \mathrm{g} / \mathrm{g}$ ) for HF and LF groups. The mean RIN obtained for all extracted samples from both groups was of $7.1 \pm 0.9$. This value is higher than 6, the threshold for high- and low-quality RNA defined by Schroeder et al. [63]. SCD gene expression was not affected ( $4.85 \pm 1.37$ vs. $5.81 \pm 2.15 \mathrm{AU})$ by the dietary treatment, similarly to what happened to the intramuscular fat percentage and the fatty acid profile. This result agrees with those authors who described SCD expression level as an indicator of intramuscular fat development $[64,65]$ and quality in ruminants and nonruminants. Therefore, SCD should be a key regulator of muscle metabolism by facilitating lipid biosynthesis and by suppressing fatty acid degradation. In contrast, some authors reported opposite results. Hiller et al. [66] and Hiller et al. [67] described differences in SCD gene expression in bovines fed different diets. In particular, in the first trial, these authors did not find significant differences in intramuscular fat content while, in the second one, lower SCD gene expression was correlated with lower C14:1 and C16:1 content in the muscle. Similarly, Urrutia et al. [68] found a lower SCD gene expression and a lower C18:1 content in the meat from lambs fed with a diet higher in linolenic acid. In addition, Waters et al. [69] and Ebrahimi et al. [70] reported a negative relationship between SCD gene expression and diet n-3 PUFA in meat from cattle and lambs, respectively. 


\section{Conclusions}

Despite the differences between the two diets, mainly in linoleic and linolenic acid, both meat fatty acids profile and gene expression were unchanged. In general, an absolute functional genomic correlation between the expression of genes and gene products was not obtained; thus, further investigations are needed to address developmental stage dependencies, transcriptional, post-transcriptional, translational and post-translational control mechanisms as well as overlapping or conflicting effects of simultaneously proceeding, tissue-specific processes of substrate uptake, lipogenesis, lipolysis and lipid release.

Author Contributions: Conceptualization F.I. and P.I.; methodology M.G. and N.M.; software M.F.; formal analysis P.I., M.F., F.S., N.M. and R.T.; resources F.I.; data curation N.M. and B.D.; writingoriginal draft preparation F.I.; writing — review and editing P.L. and R.T.; supervision P.L. and R.T.; project administration P.L. and R.T. All authors have read and agreed to the published version of the manuscript.

Funding: This research received no external funding.

Institutional Review Board Statement: The study was conducted according to the guidelines of the Declaration of Helsinki and approved by the Ethics Committee of University of Naples Federico II (PG/2021/0044033).

Informed Consent Statement: Not applicable.

Data Availability Statement: The data presented in this study are available on request from the corresponding author.

Acknowledgments: The authors wish to thank Franco Barchesi (Azienda Barchesi, Cassino, Frosinone, Italy) for his availability and technical support.

Conflicts of Interest: The authors declare no conflict of interest.

\section{References}

1. Campanile, G.; Di Palo, R.; Infascelli, F.; Gasparrini, B.; Neglia, G.; Zicarelli, F.; D’Occhio, M.J. In-fluence of rumen protein degradability on productive and reproductive performance in buffalo cows. Reprod. Nutr. Dev. 2003, 43, 557-566. [CrossRef] [PubMed]

2. Cutrignelli, M.I.; Piccolo, G.; D’Urso, S.; Calabrò, S.; Bovera, F.; Tudisco, R.; Infascelli, F. Urinary excretion of purine derivatives in dry buffalo and Fresian cows. Ital. J. Anim. Sci. 2007, 6, 563-566. [CrossRef]

3. Calabrò, S.; Infascelli, F.; Tudisco, R.; Musco, N.; Grossi, M.; Monastra, G.; Cutrignelli, M.I. Estimation of in vitro methane production in buffalo and cow. Buffalo Bull. 2013, 32, 924-927.

4. Tufarelli, V.; Dario, M.; Laudadio, V. Diet composition and milk characteristics of Mediterranean water buffaloes reared in Southeastern Italy during spring season. Livest. Res. Rural Dev. 2008, 20, 10.

5. Tudisco, R.; Cutrignelli, M.I.; Calabrò, S.; Grossi, M.; Musco, N.; Monastra, G.; Infascelli, F. Milk CLA content and $\Delta 9$ desaturase activity in buffalo cows along the lactation. Buffalo Bull. 2013, 32, 1330-1333.

6. Becskei, Z.; Savić, M.; Ćirković, D.; Rašeta, M.; Puvača, N.; Pajić, M.; Đorđević, S.; Paskaš, S. Assessment of Water Buffalo Milk and Traditional Milk Products in a Sustainable Production System. Sustainability 2020, 12, 6616. [CrossRef]

7. Infascelli, F.; Gigli, S.; Campanile, G. Buffalo meat production: Performance infra vitam and quality of meat. Vet. Res. Commun. 2004, 28, 143-148. [CrossRef] [PubMed]

8. Giordano, G.; Guarini, P.; Ferrari, P.; Biondi-Zoccai, G.; Schiavone, A.; Giordano, A. Beneficial impact on cardiovascular risk profile of water buffalo meat consumption. Eur. J. Clin. Nutr. 2010, 64, 1000-1006. [CrossRef] [PubMed]

9. Cavaliere, G.; Trinchese, G.; Musco, N.; Infascelli, F.; De Filippo, C.; Mastellone, V.; Morittu, V.M.; Lombardi, P.; Tudisco, R.; Grossi, M.; et al. Milk from cows fed a diet with a high forage: Concentrate ratio improves inflammatory state, oxidative stress, and mitochondrial function in rats. J. Dairy Sci. 2018, 101, 1843-1851. [CrossRef] [PubMed]

10. Griinari, J.M.; Bauman, D.E. Biosynthesis of conjugated linoleic acid and its incorporation into meat and milk in ruminants 1999. In Advances in Conjugated Linoleic Acid Reserch; Yurawecz, M.P., Mossoba, M.M., Kramer, J.K.G., Pariza, M.W., Nelson, G.J., Eds.; AOCS Press: Champaign, IL, USA, 2003; Volume 1, pp. 180-220.

11. Griinari, J.M.; Corl, B.A.; Lacy, S.H.; Chouinard, P.Y.; Nurmela, K.V.V.; Bauman, D.E. Conjugated Linoleic Acid Is Synthesized Endogenously in Lactating Dairy Cows by D9-Desaturase. J. Nutr. 2000, 130, 2285-2291. [CrossRef]

12. Lock, A.L.; Garnsworthy, P.C. Independent effects of dietary linoleic and linolenic fatty acids on the conjugated linoleic acid content of cow's milk. Anim. Sci. 2002, 74, 163-176. [CrossRef] 
13. Piperova, L.S.; Sampugna, J.; Teter, B.B.; Kalscheur, K.F.; Yurawecz, M.P.; Ku, Y.; Morehouse, K.M.; Erdman, R.A. Duodenal and Milk Trans Octadecenoic Acid and Conjugated Linoleic Acid (CLA) Isomers Indicate that Postabsorptive Synthesis Is the Predominant Source of cis-9-Containing CLA in Lactating Dairy Cows. J. Nutr. 2002, 132, 1235-1241. [CrossRef]

14. Kay, J.K.; Mackle, T.R.; Auldist, M.J.; Thompson, N.A.; Bauman, D.E. Endogenous synthesis of cis-9, trans-11 conjugated linoleic acid in pasture-fed dairy cows. J. Dairy Sci. 2002, 85, 176. [CrossRef]

15. Loor, J.J.; Herbein, J.H.; Polan, C.E. Trans18:1 and 18:2 Isomers in Blood Plasma and Milk Fat of Grazing Cows Fed a Grain Supplement Containing Solvent-Extracted or Mechanically Extracted Soybean Meal. J. Dairy Sci. 2002, 85, 1197-1207. [CrossRef]

16. Gillis, M.H.; Duckett, S.K.; Sackman, J.S.; Keisler, D.H. Effect of rumen-protected conjugated linoleic acid (CLA) or linoleic acid on leptin and CLA content of bovine adipose depots. J. Anim. Sci. 2003, 81, 12.

17. Bolte, M.R.; Hess, B.W.; Means, W.J.; Moss, G.E.; Rule, D.C. Feeding lambs high-oleate or high linoleate safflower seeds differentially influences carcass fatty acid composition. J. Anim. Sci. 2002, 80, 609-616. [CrossRef]

18. Yurawecz, M.P.; Roach, J.A.G.; Sehat, N.; Mossoba, M.M.; Kramer, J.K.G.; Fritsche, J.; Steinhart, H.; Ku, Y. A new conjugated linoleic acid isomer, 7 trans, 9 cis-octadecadienoic acid, in cow milk, cheese beef and human milk and adipose tissue. Lipids 1998, 33, 803-809. [CrossRef] [PubMed]

19. Parodi, P.W. Conjugated linoleic acid and other anticarcinogenic agents of bovine milk fat. J. Dairy Sci. 1999, 82, 1339-1349. [CrossRef]

20. Ward, R.J.; Travers, M.T.; Richards, S.E.; Vernon, R.G.; Salter, A.M.; Buttery, P.J.; Barber, M.C. Stearoyl-CoA desaturase mRNA is transcribed from a single gene in the ovine genome. Biochim. Biophys. Acta 1998, 1391, 145-156. [CrossRef]

21. Chung, M.; Ha, S.; Jeong, S.; Bok, J.; Cho, K.; Baik, M.; Choi, Y. Cloning and characterization of bovine stearoyl CoA desaturasel cDNA from adipose tissues. Biosci. Biotechnol. Biochem. 2000, 64, 1526-1530. [CrossRef] [PubMed]

22. Bernard, L.; Leroux, C.; Hayes, H.; Gautier, M.; Chilliard, Y.; Martin, P. Characterization of the caprine stearoyl- CoA desaturase gene and its mRNA showing an unsually long 3'-UTR sequence arising from a single exon. Gene 2001, 281, 53-61. [CrossRef]

23. Moioli, B.; Orrù, L.; Catillo, G.; Congiu, G.B.; Napolitano, F. Partial sequencing of Stearoyl-CoA desaturase gene in buffalo. Ita. J. Anim. Sci. 2005, 4, 25-27. [CrossRef]

24. Gu, M.; Cosenza, G.; Iannaccone, M.; Macciotta, N.P.P.; Guo, Y.; Di Stasio, L.; Pauciullo, A. The single nucleotide polymorphism g.133A > C in the stearoyl CoA desaturase gene (SCD) promoter affects gene expression and quali-quantitative properties of river buffalo milk. J. Dairy Sci. 2019, 102, 442-451. [CrossRef] [PubMed]

25. Medrano, J.F.; Johnson, A.; DePeters, E.J.; Islas, A. Genetic modification of the composition of milk fat: Identification of polymorphisms within the bovine stearoyl-CoA desaturase gene. J. Dairy Sci. 1999, 82, 71.

26. Martin, G.S.; Lunt, D.K.; Britain, K.G.; Smith, S.B. Postnatal development of stearoyl coenzyme A desaturase gene expression and adiposity in bovine subcutaneous adipose tissue. J. Anim. Sci. 1999, 77, 630-636. [CrossRef] [PubMed]

27. Qin, N.; Bayat, A.; Trevisi, E.; Minuti, A.; Kairenius, P.; Viitala, S.; Mutikainen, M.; Leskinen, H.; Elo, K.; Kokkonen, T.; et al. Dietary supplement of conjugated linoleic acids or polyunsaturated fatty acids suppressed the mobilization of body fat reserves in dairy cows at early lactation through different pathways. J. Dairy Sci. 2018, 101, 7954-7970. [CrossRef]

28. Kim, H.J.; Miyazaki, M.; Ntambi, J.M. Dietary cholesterol opposes PUFA-mediated repression of the stearoyl-CoA desaturase-1 gene by SREBP-1 independent mechanism. J. Lipid Res. 2002, 43, 1750-1757. [CrossRef]

29. Ntambi, J.M. Regulation of stearoyl-CoA desaturase by polyunsatured fatty acids and cholesterol. J. Lipid Res. 1999, 40, 1549-1558 [CrossRef]

30. Singh, K.; Hartley, D.G.; MC Fadden, T.B.; Mackenzie, D.D.S. Dietary fat regulates mammary stearoyl CoA desaturase expression and activity in lactating mice. J. Dairy Res. 2004, 71, 1-6. [CrossRef] [PubMed]

31. Bernard, L.; Rouel, J.; Leroux, C.; Ferlay, A.; Faulconnier, Y.; Legrand, P.; Chilliard, Y. Mammary Lipid Metabolism and Milk Fatty Acid Secretion in Alpine Goats Fed Vegetable Lipids. J. Dairy Sci. 2005, 88, 1478-1489. [CrossRef]

32. Daniel, Z.C.T.R.; Wynn, R.J.; Salter, A.M.; Buttery, P.J. Differing effects of forage and concentrate diets on the oleic acid and conjugated linoleic acid content of sheep tissues: The role of stearoyl-CoA desaturase. J. Anim. Sci. 2004, 82, 747-758. [CrossRef] [PubMed]

33. Tudisco, R.; Calabrò, S.; Cutrignelli, M.I.; Moniello, G.; Grossi, M.; Gonzalez, O.J.; Piccolo, V.; Infascelli, F. Influence of organic systems on Stearoyl-CoA desaturase in goat milk. Small Rum. Res. 2012, 106, 37-42. [CrossRef]

34. Tudisco, R.; Grossi, M.; Calabrò, S.; Cutrignelli, M.I.; Musco, N.; Addi, A.; Infascelli, F. Influence of pasture on goat milk fatty acids and Stearoyl-CoA desaturase expression in milk somatic cells. Small Rum. Res. 2014, 122, 38-43. [CrossRef]

35. Tudisco, R.; Morittu, V.M.; Addi, L.; Moniello, G.; Grossi, M.; Musco, N.; Grazioli, R.; Mastellone, V.; Pero, M.E.; Lombardi, P.; et al. Influence of pasture on stearoyl-coa desaturase and mirna 103 expression in goat milk: Preliminary results. Animals $2019,9,606$. [CrossRef] [PubMed]

36. Tudisco, R.; Chiofalo, B.; Addi, L.; Lo Presti, V.; Rao, R.; Calabro', S.; Musco, N.; Grossi, M.; Cutrignelli, M.I.; Mastellone, V.; et al. Effect of hydrogenated palm oil dietary supplementation on milk yield and composition, fatty acids profile and Stearoyl-CoA desaturase expression in goat milk. Small Rum. Res. 2015, 132, 72-78. [CrossRef]

37. Tudisco, R.; Chiofalo, B.; Lo Presti, V.; Morittu, V.M.; Moniello, G.; Grossi, M.; Musco, N.; Grazioli, R.; Mastellone, V.; Lombardi, P.; et al. Influence of feeding linseed on SCD activity in grazing goat mammary glands. Animals 2019, 9, 786. [CrossRef] [PubMed] 
38. Lee, J.S.; Pinnamaneni, S.K.; Eo, S.J.; Cho, I.H.; Pyo, J.H.; Kim, C.K.; Sinclair, A.J.; Febbraio, M.A.; Watt, M.J. Saturated, but not n-6 polyunsaturated, fatty acids induce insulin resistance: Role of intramuscular accumulation of lipid metabolites. J. Appl. Physiol. 2006, 100, 1467-1474. [CrossRef]

39. Pinnamaneni, S.; Southgate, R.; Febbraio, M.; Watt, M. Stearoyl CoA desaturase 1 is elevated in obesity but protects against fatty acid-induced skeletal muscle insulin resistance in vitro. Diabetologia 2006, 49, 3027-3037. [CrossRef]

40. Kus, V.; Prazak, T.; Brauner, P.; Hensler, M.; Kuda, O.; Flachs, P.; Janovska, P.; Medrikova, D.; Rossmeisl, M.; Jilkova, Z.; et al. Induction of muscle thermogenesis by high-fat diet in mice: Association with obesity-resistance. Am. J. Physiol. Endocrinol. Metab. 2008, 295, E356-E367. [CrossRef] [PubMed]

41. Pavan, E.; Duckett, S.K. Corn oil supplementation to steers grazing endophyte-free tall fescue. II. Effects on longissimus muscle and subcutaneous adipose fatty acid composition and stearoyl-CoA desaturase activity and expression. J. Anim. Sci. 2007, 85, 1731-1740. [CrossRef]

42. Janovská, A.; Hatzinikolas, G.; Mano, M.; Gary, A. Wittert The effect of dietary fat content on phospholipid fatty acid profile is muscle fiber type dependent. Am. J. Physiol. Endocrinol. Metab. 2010, 298, E779-E786. [CrossRef]

43. Pauciullo, A.; Cosenza, G.; D'Avino, A.; Colimoro, L.; Nicodemo, D.; Coletta, A.; Feligini, M.; Marchitelli, C.; Di Berardino, D.; Ramunno, L. Sequence analysis and genetic variability of stearoyl CoA desaturase (SCD) gene in the Italian Mediterranean river buffalo. Mol. Cell. Probes 2010, 24, 407-410. [CrossRef] [PubMed]

44. Pauciullo, A.; Cosenza, G.; Steri, R.; Coletta, A.; La Battaglia, A.; Di Berardino, D.; Macciotta, N.P.P.; Ramunno, L. A single nucleotide polymorphism in the promoter region of river buffalo stearoyl CoA desaturase gene (SCD) is associated with milk yield. J. Dairy Res. 2012, 79, 429-435. [CrossRef]

45. Yadav, P.; Kumar, P.; Mukesh, M.; Kataria, R.S.; Yadav, A.; Mohanty, A.K.; Mishra, B.P. Kinetics of lipogenic genes expression in milk purified mammary epithelial cells (MEC) across lactation and their correlation with milk and fat yield in buffalo. Res. Vet. Sci. 2015, 99, 129-136. [CrossRef]

46. Janmeda, M.; Kharadi, V.; Pandya, G.; Brahmkshtri, B.; Ramani, U.; Tyagi, K. Relative gene expression of fatty acid synthesis genes at 60 days postpartum in bovine mammary epithelial cells of Surti and Jafarabadi buffaloes. Vet. World 2017, 10, 467-476. [CrossRef] [PubMed]

47. Li, Z.; Lu, S.; Cui, K.; Shafique, L.; Rehman, S.; Luo, C.; Wang, Z.; Ruan, J.; Qian, Q.; Liu, Q. Fatty acid biosynthesis and transcriptional regulation of Stearoyl-CoA Desaturase 1 (SCD1) in buffalo milk. BMC Genet. 2020, 21, 23. [CrossRef] [PubMed]

48. AOAC. Official Methods of Analysis, 19th ed.; AOAC: Arlington, VA, USA, 2012.

49. Van Soest, P.J.; Robertson, J.B.; Lewis, B.A. Methods for dietary fiber, neutral detergent fiber, and non starch polysaccharides in relation to animal nutrition. J. Dairy Sci. 1991, 74, 3583-3597. [CrossRef]

50. INRA. Alimentation Des Ruminants; INRA: Paris, France, 1978.

51. Folch, J.; Lees, M.; Sloane-Stanley, G.H.S. A simple method for the isolation and purification of total lipids from animal tissues. J. Biol. Chem. 1957, 226, 497-509. [CrossRef]

52. Christie, W.W. A simple procedure of rapid transmethylation of glycerolipids and cholesteryl esters. J. Lipid Res. 1982, 23, 1072-1075. [CrossRef]

53. SAS 2000. SAS Institute, NC, USA. Available online: https://support.sas.com/en/software/system-2000-support.html (accessed on 10 October 2021).

54. Calabrò, S.; Cutrignelli, M.I.; Gonzalez, O.J.; Chiofalo, B.; Grossi, M.; Tudisco, R.; Panetta, C.; Infascelli, F. Meat quality of buffalo young bulls fed faba bean as protein source. Meat Sci. 2014, 96, 591-596. [CrossRef]

55. Valsta, L.M.; Tapanainen, H.; Mannisto, S. Meat fats in nutrition-A review. Meat Sci. 2005, 70, 525-530. [CrossRef] [PubMed]

56. Scerra, M.; Caparra, P.; Foti, F.; Cilione, C.; Zappia, G.; Motta, C.; Scerra, V. Intramuscular fatty acid composition of lambs fed diets containing alternative protein sources. Meat Sci. 2011, 87, 229-233. [CrossRef] [PubMed]

57. Cutrignelli, M.I.; Calabrò, S.; Bovera, F.; Tudisco, R.; D’Urso, S.; Marchiello, M.; Piccolo, V.; Infascelli, F. Effects of two protein sources and energy level of diet on the performance of young Marchigiana bulls. 2. Meat quality. Ital. J. Anim. Sci. 2008, 7, 271-285. [CrossRef]

58. Woods, V.B.; Fearon, E.A. Dietary sources of unsaturated fatty acids for animals and their transfer into meat, milk and eggs: A review. Livest. Sci. 2009, 126, 1-20. [CrossRef]

59. Hidiroglu, N.; McDowell, L.R.; Johnson, D.D. Effect of diet on animal performance, lipid composition of subcutaneous adipose tissue and liver tissue of beef cattle. Meat Sci. 1987, 20, 195-210. [CrossRef]

60. Mitchell, G.E.; Reed, A.W.; Rogers, S.A. Influence of feeding regime on the sensory qualities and fatty acid contents of beefsteaks. J. Food Sci. 1991, 56, 1102-1103. [CrossRef]

61. Rowe, A.; Macedo, F.A.F.; Visentainer, J.V.; Souza, N.E.; Matsushita, M. Muscle composition and fatty acid profile in lambs fattened in dry lot or pasture. Meat Sci. 1999, 51, 283-288. [CrossRef]

62. Lock, A.L.; Garnsworthy, P.C. Seasonal variation in milk conjugated linoleic acid and 9-desaturase activity in dairy cows. Livest. Prod. Sci. 2003, 79, 47-59. [CrossRef]

63. Schroeder, A.; Mueller, O.; Stocker, S.; Salowsky, R.; Leiber, M.; Gassmann, M.; Lightfoot, S.; Menzel, W.; Granzow, M.; Ragg, T. The RIN: An RNA integrity number for assigning integrity values to RNA measurements. BMC Mol. Biol. 2003, 7, 3. [CrossRef] [PubMed] 
64. Cedernaes, J.; Alsiö, J.; Västermark, Å.; Risérus, U.; Schiöth, H.B. Adipose tissue stearoyl-CoA desaturase 1 index is increased and linoleic acid is decreased in obesity-prone rats fed a high-fat diet. Lipids Health Dis. 2013, 12, 2. [CrossRef]

65. Wang, Y.H.; Bower, N.I.; Reverter, A.; Tan, S.H.; De Jager, N.; Wang, R.; McWilliam, S.M.; Café, L.M.; Greenwood, P.L.; Lehnert, S.A. Gene expression patterns during intramuscular fat development in cattle. J. Anim. Sci. 2009, 87, 119-130. [CrossRef] [PubMed]

66. Hiller, B.; Herdmann, A.; Nuernberg, K. Dietary n-3 Fatty Acids Significantly Suppress Lipogenesis in Bovine Muscle and Adipose Tissue: A Functional Genomics Approach. Lipids 2011, 46, 557-567. [CrossRef]

67. Hiller, B.; Hocquette, J.; Cassar-Malek, I.; Nuernberg, G.; Nuernberg, K. Dietary n-3 PUFA affect lipid metabolism and tissue function-related genes in bovine muscle. Br. J. Nutr. 2012, 108, 858-863. [CrossRef] [PubMed]

68. Urrutia, O.; Mendizaba, J.A.; Insausti, K.; Soret, B.; Purroy, A.; Arana, A. Effects of Addition of Linseed and Marine Algae to the Diet on Adipose Tissue Development, Fatty Acid Profile, Lipogenic Gene Expression, and Meat Quality in Lambs. PLoS ONE 2016, 11, e0156765. [CrossRef] [PubMed]

69. Waters, S.M.; Kelly, J.P.; O’Boyle, P.; Moloney, A.P.; Kenny, D.A. Effect of level and duration of dietary n-3 polyunsaturated fatty acid supplementation on the transcriptional regulation of $\Delta 9$-desaturase in muscle of beef cattle. J. Anim. Sci. 2009, 87, 244-253. [CrossRef] [PubMed]

70. Ebrahimi, M.; Rajion, M.A.; Goh, Y.M.; Sazili, A.Q.; Schonewille, J.T. Effect of Linseed Oil Dietary Supplementation on Fatty Acid Composition and Gene Expression in Adipose Tissue of Growing Goats. BioMed Res. Int. 2013, 2013, 194625. [CrossRef] [PubMed] 